\title{
The Relationship of Indonesian Language Learning with the Environment
}

\author{
Siti Ari Fah \\ Universitas Negeri Padang-FBS \\ sitiarifah0897@gmail.com
}

The environment is an influential component in implementing teaching and learning activities. The environment can also support teaching and learning activities in schools. Schools with a clean environment will make students learn comfortably and vice versa. However, our level of awareness of the importance of the environment is still very minimal. Teachers as educators play an important role in teaching environmental education and fostering awareness of students about the environment.

Environmental problems are not a new problem in Indonesia. One of the efforts to overcome environmental problems is to instill the importance of protecting the environment in young people from an early age. Instilling a sense of responsibility and awareness of protecting the environment can be included in environmental materials in Indonesian language learning. According to Ramadhan, Sukma, and Indriyani (2019) the use of environmental themes in text learning can trigger student interest in learning languages and can increase students' knowledge of the environment.

Learning about environmental material, directly or indirectly, can develop the mindset of students. The existence of environmental material in Indonesian language learning can make students think about positive and negative things for the environment. According to Putri, Ramadhan, and Gani (2012) thinking is the human ability to discuss and find the meaning of a reality. Students are expected to think and adjust a lifestyle that will reduce our burden on the environment.

Learning Indonesian can improve the communication skills of students in the community. To be able to develop communicative skills, students can use material on global issues, especially about the environment. In communicating, it is necessary to pay attention to politeness in speaking. According to Halawa, Gani, and Ramadhan (2019), politeness to speak is politeness and subtlety in using language when communicating. People who speak politely tend to get a positive response from the interlocutor. Language is used as a tool for someone to communicate with other people (Putri, Gani, and Ramadhan, 2019). A person's strong ability to communicate with others can be used to influence and invite them to care more about the environment. 
In addition, environmental-based Indonesian language learning can increase the creativity of students. According to Piliang, Atmazaki, and Ramadhan (2014) creativity is the ability to create new combinations, based on existing data, information, or elements. Students are expected to be creative in producing or working on a project that can provide benefits to the environment, such as making hand-powered dishwashers that do not require electricity and little water, salt lamps that can be used when the power fails, and various other inventions. These various discoveries are expected to provide changes to the environment.

Environment-based learning aims to make students participate in protecting the environment. This can be achieved by implementing lesson study in Indonesian language learning. According to Putri, Atmazaki, and Ramadhan (2013) lesson study is one of the coaching efforts to improve the learning process carried out by a group of teachers collaboratively and continuously in planning, implementing, observing, and reporting the results of reflections on their learning activities. So that students can participate in protecting the environment, it is important to develop knowledge about the environment, environmental awareness and behavior change towards the environment.

Advances in science and technology, especially in the field of communication, have led to the flow of information through telephone, radio, television and recordings. Students are expected to take advantage of these advances, one of which is in learning about environmental materials. Students can listen to various information broadcast through the media. Listening is one of the language skills that is very important for teachers and students to pay attention to in learning, especially those related to the environment (Sukma, Mahyudin, Rahmatina, and Suriani, 2018).

The use of literacy media in environment-based Indonesian language learning can also increase students' awareness of the environment. Good literacy skills will help students understand learning so that it can imply it in life. Literacy is closely related to the term proficient discourse, namely the ability of all languages including the ability to listen, speak, read, and write, as well as the ability to construct the elements contained in it (Sukma, Indrawati, and Suriani, 2019).

According to Amelia, Sukma, and Asma (2015) students who develop writing skills from an early age acquire valuable tools for learning, communication, self-expression and helping them succeed in school and society. Students who have good writing skills can participate in increasing public awareness of the environment, one of which is by producing persuasion texts which essentially invite the public to care about the environment. The various works of the students' writing skills are expected to change people's perceptions of 
the environment. It is hoped that the community will pay more attention and care about environmental cleanliness.

Learning about the environment can have a positive impact on the knowledge, values and attitudes of students in relation to the environment (Sukma, Ramadhan, and Indriyani, 2020). Environmental education can help students rethink the relationship between humans and their environment, begin to understand the environment, become aware of various environmental problems and think of solutions to these problems. Environmental education can be applied to all students of different ages.

Based on the questionnaire I distributed to UNP Semester 5 students of 2020, the following data were obtained. The first statement, namely environmental material needs to be included in Indonesian language learning, 50\% agreed, 46.7\% strongly agreed, 3.3\% disagreed, and $0 \%$ disagreed. The second statement, namely environmental material is an interesting topic to study, especially in Indonesian language learning, 70\% agreed, $26.7 \%$ strongly agreed, $3.3 \%$ disagreed, and $0 \%$ disagreed. The third statement, namely environmental preservation efforts can be included in Indonesian reading texts, $63.3 \%$ strongly agree, $33.3 \%$ agree, $3.4 \%$ disagree, and $0 \%$ disagree. The fourth statement, namely the teacher has an important contribution in introducing environmental knowledge through classroom learning, $60 \%$ strongly agree, $36.7 \%$ agree, $3.3 \%$ disagree, and $0 \%$ disagree. The fifth statement, namely environmental-based Indonesian language learning can increase the creativity of students, $50 \%$ agreed, $46.7 \%$ strongly agreed, $3.3 \%$ disagreed, and $0 \%$ disagreed.

The sixth statement, namely environmental material is material that is closely related to everyday life, $63.3 \%$ strongly agree, $33.3 \%$ agree, $3.4 \%$ disagree, and $0 \%$ disagree. The seventh statement, namely learning about environmental material directly or indirectly can develop the mindset of students, $60 \%$ agreed, $36.7 \%$ strongly agreed, $3.3 \%$ disagreed, and $0 \%$ disagreed. The eighth statement, namely learning Indonesian can improve students' communication skills in the community, $53.3 \%$ agreed, $43.3 \%$ strongly agreed, $3.4 \%$ disagreed, and $0 \%$ disagreed. The ninth statement, namely the environment can be used as a medium in Indonesian language learning, 50\% strongly agree, 46.7\% agree, 3.3\% disagree, and $0 \%$ disagree. The tenth statement, namely the environmental material in Indonesian language learning can foster student attitudes that care about the environment, $56.7 \%$ strongly agree, $36.7 \%$ agree, $3.3 \%$ disagree, $3.3 \%$ disagree. 
From the results of the author's research above, it can be concluded that environmental material is very important to be applied in Indonesian language learning. Environmental material is an interesting topic to study, especially in learning Indonesian. Environmental preservation efforts can be included in Indonesian reading texts. The teacher can imply learning Indonesian with the environment, one of which is by looking for relevant examples so that students understand better the material provided. 


\section{REFERENCE}

Amelia, Rizki, Elfia Sukma, dan Nur Asma. (2015). Pembelajaran Menulis Laporan Percoban dengan Pendekatan Saintifik di Sekolah Dasar. Prosiding Seminar Nasional Jurusan PGSD, Vol 1 (1)

Halawa, Noibe, Erizal Gani, dan Syahrul Ramadhan. (2019). Kesantunan Berbahasa Indonesia dalam Tindak Tutur Melarang dan Mengkritik pada Tujuh Etnis. Jurnal Bahasa, dan Sastra dan Pengajarannya, Vol. 15, No.2

Piliang, Wilda Srihastuty Handayani, Atmazaki, dan Syahrul Ramadhan. (2014). Kontribusi Kemampuan Apresiasi Sastra dan Berpikir Kreatif terhadap Keterampilan Bermain Drama pada Siswa Kelas XII IPS SMA Negeri 2 Rengat Kabupaten Indragiri Hulu. Jurnal Bahasa, Sastra dan Pembelajaran. Vol. 2, No. 2

Putri, Gusnita Roza, Syahrul Ramadhan, dan Erizal Gani. (2012). Hubungan Kemampuan Berpikir Logis dengan Kemampuan Menulis Karangan Argumentasi Siswa Kelas X SMA Negeri 1 Rao Pasaman Barat. Jurnal Pendidikan Bahasa dan Sastra Indonesia, Vol. 1 No. 1

Putri, Idra, Atmazaki, dan Syahrul Ramadhan. (2013). Pelaksanaan Lesson Study dalam Pembelajaran Bahasa Indonesia Siswa Kelas VII 5 MTsN Lubuk Buaya Padang. Jurnal Bahasa, Sastra dan Pembelajaran, Volume 1 Nomor 1

Putri, Silvia Wina, Erizal Gani, dan Syahrul Ramadhan. (2019). Penggunaan Prinsip Kesantunan Berbahasa dalam Talk Show Mata Najwa Edisi 100 Hari Anies-Sandi Memerintah Jakarta. Jurnal Bahasa, Sastra, dan Pengajarannya, Vol. 15 (1)

Ramadhan, S., Elfia Sukma, dan V. Indriyani. (2019). Environmental education and disaster mitigation through language learning. IOP Conference Series: Earth and Environmental Science, 314

Sukma, Elfia, Ritawati Mahyudin, Rahmatina, and Ari Suriani. (2018). Problems in Oral Language Teaching in Primary School. Advances in Social Science, Education and Humanities Research, Volume 301

Sukma, Elfia, Syahrul Ramadhan, dan V. Indriyani. (2020). Integration of Environmental Education in Elementary Schools. PhysicsIOP Conf. Series: Journal of Physics: Conf. Series 1481

Sukma, Elfia, Tin Indrawati, dan Ari Suriani. (2019). Penggunaan Media Literasi Kelas Awal di Sekolah Dasar. Jurnal Inovasi Pendidikan dan Pembelajaran Sekolah Dasar. Volume 3, Nomor 2 


\section{LAMPIRAN}

Tabel 1

\begin{tabular}{|c|c|c|c|c|c|}
\hline No. & Statement & SS & $\mathbf{S}$ & KS & TS \\
\hline 1. & $\begin{array}{l}\text { Environmental materials need to be included in } \\
\text { Indonesian language learning }\end{array}$ & $46,7 \%$ & $50 \%$ & $0 \%$ & $3,3 \%$ \\
\hline 2. & $\begin{array}{l}\text { Environmental material is an interesting topic } \\
\text { to study, especially in learning Indonesian }\end{array}$ & $26,7 \%$ & $70 \%$ & $0 \%$ & $3,3 \%$ \\
\hline 3. & $\begin{array}{l}\text { Environmental conservation efforts can be } \\
\text { included in Indonesian reading texts }\end{array}$ & $63,3 \%$ & $33,3 \%$ & $0 \%$ & $3,4 \%$ \\
\hline 4. & $\begin{array}{l}\text { Teachers have an important contribution in } \\
\text { introducing environmental knowledge through } \\
\text { classroom learning }\end{array}$ & $60 \%$ & $36,7 \%$ & $0 \%$ & $3,3 \%$ \\
\hline 5. & $\begin{array}{l}\text { Environmental-based Indonesian language } \\
\text { learning can increase the creativity of students }\end{array}$ & $46,7 \%$ & $50 \%$ & $0 \%$ & $3,3 \%$ \\
\hline 6. & $\begin{array}{l}\text { Environmental material is material that is } \\
\text { closely related to everyday life }\end{array}$ & $63,3 \%$ & $33,3 \%$ & $0 \%$ & $3,4 \%$ \\
\hline 7. & $\begin{array}{l}\text { Learning about environmental material, } \\
\text { directly or indirectly, can develop the mindset } \\
\text { of students }\end{array}$ & $36,7 \%$ & $60 \%$ & $0 \%$ & $3,3 \%$ \\
\hline 8. & $\begin{array}{l}\text { Learning Indonesian can improve students' } \\
\text { communication skills in the community }\end{array}$ & $43,3 \%$ & $53,3 \%$ & $0 \%$ & $3,4 \%$ \\
\hline 9. & $\begin{array}{l}\text { The environment can be used as a medium in } \\
\text { learning Indonesian }\end{array}$ & $50 \%$ & $46,7 \%$ & $0 \%$ & $3,3 \%$ \\
\hline 10. & $\begin{array}{l}\text { Environmental materials in Indonesian } \\
\text { language learning can foster student attitudes } \\
\text { that care about the environment }\end{array}$ & $56,7 \%$ & $36,7 \%$ & $3,3 \%$ & $3,3 \%$ \\
\hline
\end{tabular}

